$505.54: 504.03(477)$

2025 p.

\author{
- 3 рук \\ ьвівський н ціон льний університет імені в н \\ вул. . орошенк , 41, м. ввів, 79000, кр їн
}

ивчено еколого-геогр фічні особливості генер льного пл ну м. ьвов . ого геопросторові спекти, т їхній вплив н формув ння міської урбосистеми. ро н лізов но функціон льний розвиток л ндш фтів міст , їхню роль у поліпшенні життєвого середовищ мешк нців.

лючові слов : геопросторов структур , функціон льний розвиток л ндш фтів, генер льний пл н міст .

ізке з гострення н прикінці ст. містобудівельних, соці льно-економічних, екологічних т інших проблем розвитку ьвов зумовило н г льну потребу їхнього вирішення для поліпшення умов життєдіяльності н селення. рубіжний досвід і вітчизнян пр ктик з свідчують: розробк комплексних з ходів, 3 допомогою яких можн вирішити проблеми, що стосуються пр ктично всіх сфер життєдіяльності н селення, т кі як пошук необхідних для розвитку інвестицій, з безпечення міських жителів місцями прикл д ння пр ці, об'єкт ми соці льної, інженерної, екологічної інфр структури, розробк функціон льного зонув ння міст, визн чення територій для житлового, виробничого т іншого будівництв тощо, можлив лише 3 н явності генер льного пл ну. розвинених кр їн х світу пр ктично кожний н селений пункт з безпечений генер льним пл ном. енер льний пл н - основний вид містобудівної документ ції з пл нув ння території міст , призн чений для обгрунтув ння довготермінової (стр тегічної) політики міської р ди в пит ннях використ ння території. ого розробляють як підст ву для обгрунтув ння й ув'язки зі стр тегією розвитку території т окремих ділянок міст , які готують упр вління деп рт менту містобудув ння і прийм $є$ міськ р д . енер льний пл н повинен бути перм нентним документом, тобто т ким, у який періодично вносять корективи, зумовлені ре ліями постійних змін. сесії міської р ди 30 вересня 2010 р. розглянуто пит ння, “ ро з твердження містобудівної документ ції “ оригув ння генер льного пл ну м. ьвов ” 11 ст дія енер льний пл н”

ме цей документ визн ч тиме просторовий розвиток міст, розміщення основних об'єктів, збереження історико-культурної сп дщини, зелених зон, п рків, нових об'єктів. енпл н-це візу ліз ція м йбутнього розвитку ьвов .

ш мет : дет льно розглянути еколого-геогр фічні особливості розвитку міст , які відобр жені в генер льному пл ні, з твердженоу міською $\mathrm{p}$ дою н перспективу до 2025 р., з'ясув ти особливості геопросторового розвитку міст т його вплив н соці льно-екологічну ситу цію в приміській зоні, ох р ктеризув ти основні техніко-економічні пок зники генер льного пл ну т їхнє місце в поліпшенні соці льно-екологічної ситу ції у ьвові.

(C) 3 рук ., 2011 
ерший генер льний пл н міст ьвов розроблений у 1928-1935 рр. під керівництвом професор ьвівської політехніки . рекслер . 3 г льних рис х він відповід в суч сному генер льному пл ну. ньому вперше пост влено з вд ння перспективного розвитку міст в м сшт б х приміської зони. д іністрів в 1956 р. $з$ твердил генер льний пл н н проектний період до 1970 р., розроблений рхітектор ми . p б шем, . ерсиковим ( иївський інститут іпроміст). цьому документі н бул под льшого розвитку висловлен в 30-х рок х інженером . рекслером ідея створення еликого ьвов , що передб ч л зрост ння міст шляхом долучення пунктів приміської зони і перетворення історично утвореного р ді льного пл нув ння в $р$ ді льнокільцеве. межі міст входили сел : н півночі- олоско т боїщ, н сході- ривчиці, сіки убрицькі, н півдні - отельники, окільники, н з ході- игнівк, ев ндівк . ступні генпл ни розробляли у 1966 p. ( иївський інститут іпроміст) т 1993 р. ( ьвівський інститут крз хідцивільпроект тепер істопроект). оригув ння генпл ну 2010 р. розпоч то в 2001 р. розроблено концепцію розвитку міст , з тверджену в 2005 р. еобхідність коригув ння генер льного пл ну зумовлен соці льноекономічними змін ми в держ ві, невідповідністю прогнозов них п р метрів розвитку міст в чинному генер льному пл ні, з твердженому ухв лою ьвівської міської р ди від 29.06.1993 p. ові соці льно-економічні т політичні умови зумовили потребу територі льного прогнозув ння і містобудівного проектув ння. росл кількість різном нітних форм вл сності, у тому числі й н землю. більшил ся кількість уч сників господ рської діяльності в місті, змінил ся інвестиційн політик , в т ких умов х елементи простору міст ст ють предметом ринкових відносин, отримують ре льну в ртість т вл сність. ідбув ються зн чні структурні зміни у функціон льному використ нні території з огляду н 6 нкрутство підприємств і перерозподіл нерухомості, місто поч ло пр цюв ти в умов х ринкової економіки.

ошуки нової економічної моделі розвитку н ціон льного комплексу т інші чинники ст ли потужним к т ліз тором з гострення всіх проблем розвитку міст ьвов т н дзвич йно кту лізув ли розробку нового енер льного пл ну.

гідно з з твердженим пл ном, ьвів повинен бути б г тофункціон льним. обто передб чено одноч сно розвиток міст у $б$ г тьох н прям х - як центру культури, освіти, н уки, туризму, спорту, торгівлі, виробництв тощо. н йближчі 15 років для ьвов передб ч ється розвиток швидкими темп ми туризму і супутніх з ним систем обслуговув ння, т кож н уки й освіти, ринкової інфр структури.

огляду н розт шув ння міст н перетині тр нспортних коридорів, т кож розвиток виробництв н нових технологічних з с д х, несприятливі клім тичні умови в місті не передб чене розміщення підприємств кл су I і II з с ніт рною кл сифік цією. енер льний пл н розр хов ний н період до 2025 р., до 2012 буде втілено першу ч стину. ерспективу розвитку м. ьвов розгляд ють декв тно до змін економічної ситу ції кр їни.

жливим спектом є перспектив геопросторового розвитку міст . окрем , пл нують включення у межі ьвов близько 26 прилеглих н селених пунктів, серед них ідрясне, ясн - уськ, удно, имн од, п ївк, книлів, окільники, исиничі, инники, ідбірці, ороки- ьвівські, лехів, уров не, убр, олонк, олодноводківк , ірки, м’янопіль, олиця, ереж ни, бир нк, лі рибовичі, еликі рибовичі, сіки убрицькі. хня з г льн площ - 33 тис. г з н селенням 816 тис. осіб, у тому числі поз меж ми міст - 83 тис. осіб. зоні приміського розселення поблизу м гістр льних р ді льних доріг виділені території з г льною площею 850 г ре- 
комендов но для житлової і пов'яз ної з нею гром дської з будови. ормув ння містобудівної системи “ еликий ьвів” м є суттєвий вплив н розвиток міст , яке вн слідок цього процесу поступово перетвориться 3 комп ктного поселення в розг лужену структуру з розвинутою системою зв'язків. цьому р зі дин мік пок зників зрост ння в периферійній зоні може бути вищою, вр ховуючи меншу в ртість i, відповідно, більшу прив бливість приміських земель, що д є підст ву стверджув ти про можливість певної ст біліз ції екстенсивного зрост ння і переорієнт ції н структурні зміни в меж х міст

н чну ув гу в енер льному пл ні приділено т кож освоєнню територій у меж х міст , які нині неефективно використовують, зокрем , зб нкрутілих підприємств в тон в нт жув ч, інескоп, з воду фото-телегр фної п р тури, військових ч стин, колективних с дів.

г тогр нність проблеми реконструкції тр нспортної структури міст визн чен двом обст вин ми - міждисциплін рним х р ктером проблеми і скл дністю історично сформов ного європейського міст як об'єкт реконструкції. им зумовлен необхідність упорядкув ння отрим ння т опр цюв ння інформ ції про розвиток елементів і підсистем міст , з ур хув нням впливу демогр фічної структури, еволюції соці льної структури і змін способу життя н селення міст . юди ж н леж ть екологічні проблеми, пов'яз ні зі збереженням т відновленням природного т міського середовищ ; широкий комплекс інженерно-технічних проблем.

н йближче десятиріччя розвитком вулично-дорожної мережі передб чено будівництво внутрішнього кільця м гістр лей безперевного руху по вулицях уг нській, яйв , ев ндівській, рошенк, ипинського, л стов, огд нівській, січній $з$ розміщенням великих г р жів-стоянок у зон х тр нспортних вузлів і обмеження в'їзду в центр льну ч стину міст, т кож формув ння другого кільця - вулиці уков роектов н, яшівськ (див. т бл.), з виходом через р йони ев ндівк, ясне, боїщ до иївської тр си. центр льній ч стині міст орг ніз ція системи одностороннього руху по вулицях, створення пішохідних зон. пропонов но резервув ння коридору східної хордової м гістр лі, н ближеної до центру міст для вирішення проблеми їі будівництв при д льшому проектув нні.

к б чимо, функціонув ння містобудівної системи в жлив тр нспортн інфр структур , як потребув тиме прискореного розвитку, особливо систем гром дського тр нспорту.

оліпшенню соці льно-екологічної ситу ції в місті повинні сприяти з декл ров ні н прями реформув ння бройних сил кр їни. пропонов но виведення всіх військових об'єктів міст (дислок ція особового скл ду, техніки, скл дів інфр структури тощо) окрім підприємств військово-промислового і тих об'єктів, необхідність збереження яких у меж х міст буде обумовлен в держ вних вимог х генер льного пл ну. ині у місті є 23 ділянки 3 г льною площею 221,8 г . дну 3 н йбільших (вулиці ролейбусн - убч к ) - 13,8 г - уже успішно використовують під житлову т гром дську з будову. ередб чене створення гром дського центру н місці військової ч стини х ров - трийськ - 20,8 г . ля рекре ції пропонують ділянки н овбуш гор ев , т овбуш $26-3,5$ г.

озвиток гром дського тр нспорту пл нують шляхом реконструкції тр мв йних ліній з новою безшумною технологією, будівництво ліній у р йони ихів, івнічний, исиничі, ясне, розширення мережі тролейбусних ліній. перспективу пропонують спорудження ліній полегшеного метрополітену (систем “ д н”). иди тр нспорту н 
електричній тязі є пріоритетними 3 економічними т екологічними критеріями. втобуси зберіг ють як допоміжний вид тр нспорту. скільки повітряний б сейн міст з бруднений головно від втотр нспорту (45.8 тис. т з рік, $95 \%$ від в лового викиду) в пл ні передб чено покр щення ситу ції з вдяки розвитку вуличної мережі, вл штув ння об’їздів, п рковок і обмеження в’їзду в центр льну ч стину міст , пріоритетний розвиток гром дського електротр нспорту т велосипедного руху.

іський тр нспорт т м гістр лі з г льноміського сполучення [2]

\begin{tabular}{|c|c|c|c|c|}
\hline $\begin{array}{l}№ \\
\Pi / \Pi\end{array}$ & ок зники & $\begin{array}{c}\text { диниці } \\
\text { вимірюв ння }\end{array}$ & $\begin{array}{l}\text { уч сний } \\
\text { ст н }\end{array}$ & $\begin{array}{l}\text { озр хунковий } \\
\text { період }\end{array}$ \\
\hline 1 & \begin{tabular}{l}
\multicolumn{1}{c}{ ротяжність ліній } \\
міського тр нспорту, \\
усього \\
$-\quad$ тр мв й \\
$-\quad$ тролейбус \\
$-\quad$ втобус \\
\end{tabular} & $\begin{array}{c}\text { км, } \\
\text { подвійного шляху }\end{array}$ & $\begin{array}{c}267,4 \\
\\
36,8 \\
58,6 \\
172,0\end{array}$ & $\begin{array}{l}533,6 \\
63,2 \\
78,4 \\
392,0\end{array}$ \\
\hline 2 & $\begin{array}{l}\text { ротяжність вулиць т } \\
\text { м гістр лей, усього } \\
\text { - у тому числі: } \\
\text { м гістр лей } \\
3 \text { г льноміського т } \\
\text { р йонного зн чень }\end{array}$ & KM & $\begin{array}{l}605,1 \\
152\end{array}$ & $\begin{array}{l}935 \\
327\end{array}$ \\
\hline 3 & $\begin{array}{l}\text { ільність вуличної } \\
\text { мережі, усього }\end{array}$ & $\mathrm{KM} / \mathrm{KM}$ & 2,3 & 3,63 \\
\hline 4 & івень втомобіліз ції & $\begin{array}{c}\text { егкових м шин н } \\
1000 \text { осіб }\end{array}$ & 170 & 300 \\
\hline 5 & $\begin{array}{l}\text { ількість місць } \\
\text { зберіг ння втом шин } \\
\text { мешк нців н селеного } \\
\text { пункту з скл дом } \\
\text { п рку т вид ми: } \\
\text { легкових втомобілів, } \\
\text { усього } \\
\text { у тому числі з вид ми } \\
\text { зберіг ння: } \\
\text { - відкриті стоянки } \\
\text { - одноповерхові } \\
\text { г р жі } \\
\text { - б г топоверхові } \\
\text { г р жі } \\
\text { в нт жних } \\
\text { втомобілів, усього }\end{array}$ & шиномісць & $\begin{array}{l}120000 \\
11,158 \\
30,840 \\
1230 \\
\\
\text { ні відсутні }\end{array}$ & $\begin{array}{l}225000 \\
10000 \\
25000 \\
190000 \\
\\
30000\end{array}$ \\
\hline
\end{tabular}

ьогодні площ системи зелених н с джень 3 г льного користув ння ст новить 820 г , 3 безпеченість - 11,2 $\mathrm{m}^{2} 3$ норми $17 \mathrm{~m}^{2}$. ормув ння системи л ндш фтно-рекре ційних територій передб чене шляхом визн чення юридичних меж п рків і особливого режиму використ ння т з будови міжп ркових територій, створення і бл гоустрою 
п рків у нових р йон х міст $з$ доведенням їхньої з г льної площі до норм тивного пок зник . енер льний пл н передб ч $є$ будівництво нових п рків з г льною площею не менше 90 г і перетворення 380 г прилеглих до міст лісів рюховицького і инниківського лісництв у міські лісоп рки.

тже, у генер льному пл ні не чітко простежен концепція ст лого розвитку міст . е $з$ вжди поєдн но вирішення соці льно-економічних, соці льно-культурних т соцільно екологічних проблем.

ет , проголошен в енер льному пл ні ( ьвів, де людин почув ється комфортно), і шлях досягнення цієї мети (збереження, відродження, розвиток) не у всіх розділ х енер льного пл ну відобр жені рівноцінно.

н лізу ситу ції виплив $є$, що виробничий комплекс міст , системи міського господ рств - тр нспорт, інженерне обл дн ння і бл гоустрій території, житловий фонд не відповід ють суч сним вимог м. ерент бельність діяльності і б нкрутство б г тьох підприємств є причиною неефективного використ ння міських земель.

риродн основ міст потребує постійного н укового спостереження, проте цей розділ у пл ні не повний і потребує повноти інформ ції, як розпорошен по відомсTB X.

нтенсивний розвиток шляхом реструктуриз ції т модерніз ції територій, інтенсифік ції їхнього освоєння, ущільнення, підняття експлу т ційних т с ніт рно-екологічних якостей території, впров дження з ходів, спрямов них н досягнення безпеки прожив ння, мініміз ція з грози життю і здоров'ю людей - т кі основні н прями розвитку міст до 2025 p.

1. брель . . росторов орг ніз ція містобудівних систем / н-т регіон. осліджень кр їни. / . . брель. . : ид. дім . . ., 2004. 400 с.

2. енер льний пл н м. ьвов . сновні положення. ьвів, 2008.

3. риворучко . Q QUO VADIS, ( ув ги рецензент “ онцепції розвитку ьвов ”) пр вління великими міст ми : дмініструв ння т безпосередня демокр тія ( проблеми теорії і пр ктики) : тері ли II-ї укр.-пол. конференції / . риворучко. ьвів, 2004. 540 с.

4. $з$ рук . . ьвів у столітті : соці льно-екологічний н ліз / . $\quad$ з рук. ьвів, 2008. $348 \mathrm{c}$.

5. ос цький . . ростір міст і міськ культур / зл мі - ст.) : оногр фія / . . ос цький. ьвів : ид-во “ ьвів. політехнік ”, 2007. 2008 с.

\title{
ECOLOGICAL-GEOGRAPHICAL ASPECTS OF THE GENERAL PLAN OF LVIV CITY TILL 2025
}

\author{
M. Nazaruk \\ Ivan Franko National University of Lviv, \\ . Doroshenko St., 41, UA - 79000 Lviv, Ukraine
}

Ecological-geographical peculiarities of the General Plan of Lviv are studied. Its geospace aspects and their influence on the city urbosystem's formation have been described. Functional development of the city's landscapes and their role in improving of the city's life environment has been analyzed.

Key words: geospace structure, a functional development of landscapes, city's general plan. 
- 3 рук

ьвовский н иион льный университет имени в н ул. . орошенко, 41, г. ввов, 79000, кр ин

зучено эколого-геогр фические особенности генер льного пл н г. ьвов . го геопростр нственные спекты, их влияние н формиров ние городской урбосистемы. ро н лизиров но функцион льное р звитие л ндш фтов город , их роль в улучшении жизненной среды город .

лючевые слов : геопростр нственн я структур, функцион льное р звитие л ндш фтов, генер льный пл н город

т ття н дійшл до редколегії 07.07.2011

рийнят до друку 19.04.2011 